Emir. J. Food Agric. 2009. 21 (2): 51-63

http://cfa.uaeu.ac.ae/ejfa.shtml

\title{
Attitudes of Vegetable Farmers towards Risk in the Jordan Valley
}

\author{
Mahmoud Ali Salem Hindi \\ Department of Agricultural Economics and Agribusiness Management, \\ University of Jordan, Amman, Jordan
}

\begin{abstract}
The main objective of this study was to examine the vegetable farmers' attitudes towards risk in the Jordan Valley. In order to measure risk attitudes, utility functions for vegetable farmers in the Jordan Valley were estimated by using the Von Neumann Morgenstern model. From the estimated utility functions, the risk attitudes coefficient for each farmer was measured. Of the total random sample of 200 farmers from the middle Ghor in the Jordan Valley, a purpose sample of 50 vegetable farmers was proportionally selected, i.e. 13 farmers (26\%), 15 farmers (30\%), and 22 farmers (44\%) fell into the risk avert, risk neutral and risk taker categories, respectively. To analyze the relationship between farmers' personal characteristics such as age, education, farm size, family size, experience in agriculture and their risk attitudes, a multiple linear regression model was used. Linear, semi-log, and double-log equations were used. Of these, the semi-log equation proved the best. The regression results of the study indicated that the coefficient of farm size (X3) and the coefficient of family size (X5) were statistically significant at the $5 \%$ level of significance.
\end{abstract}

Key words: Vegetable farmers, Coefficient of farm size, Jordan Valley.

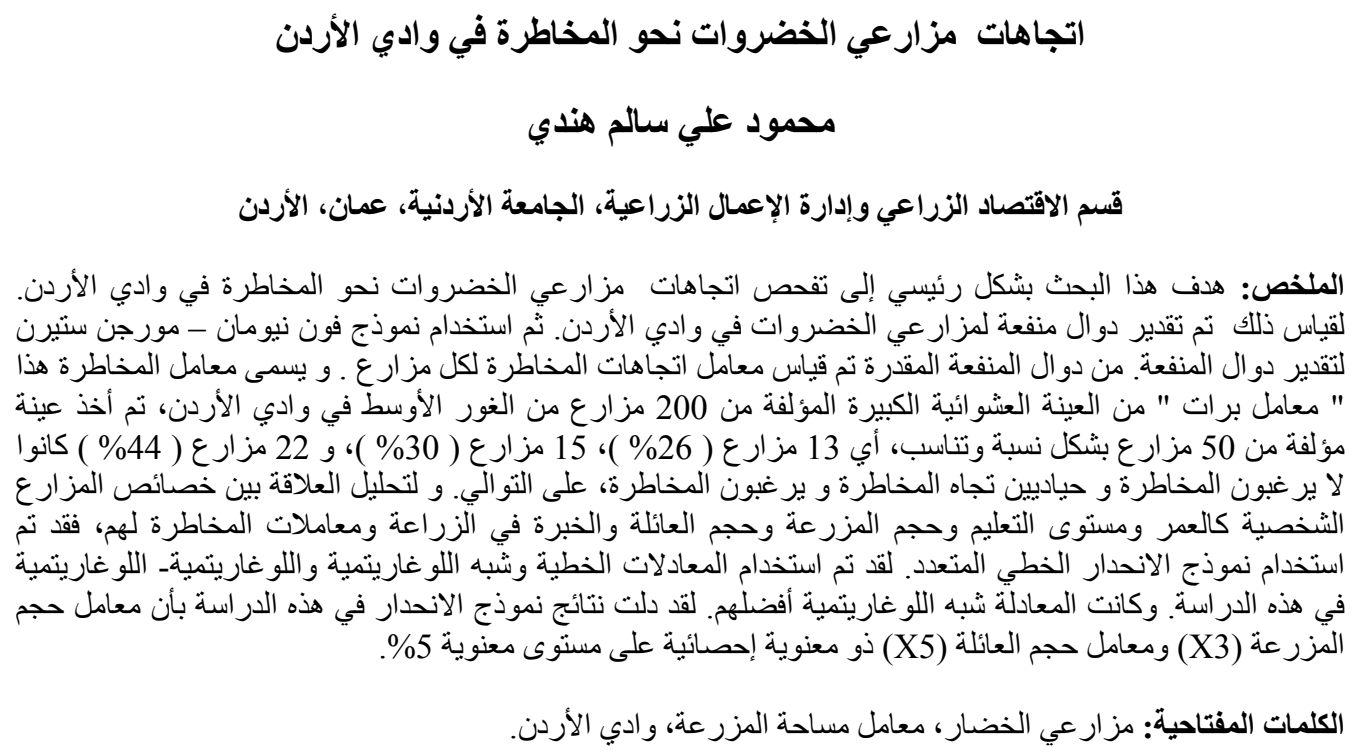

\section{Introduction}

Agriculture is considered a basic pillar of economic and social development in Jordan. During the past three decades, agriculture has also started to play a major role in protecting the environment, including the protection of bio-diversity and ensuring an environmental balance that would secure sustainable use of resources and preserve them for future generations. These principles make up the base of agricultural strategies in Jordan. The focus is no longer on the economic aspect of development alone; the social and environmental dimensions are also given importance.

A continued decline was observed in the contribution of agricultural output to the GDP, from $11 \%$ in 1992 (Department of Statistics, 1992) to $3.8 \%$ 
in 2000 (Department of Statistics, 2000), and then to 3.4\% in 2006 (Ministry of Agriculture, The National Strategy, 2006). The Agricultural Sector started to witness declining growth rates during the late 1990s. This decline was attributed to the policy of trade liberalization adopted by the Government in 1994, and to the structural adjustment program of the agricultural sector (ASAL) in 2000.

Therefore a lot of pressure must be exerted by the Government to develop the agricultural sector in order to stop further deterioration and enhance its contribution to the national economy. This is especially important given that the agricultural sector, although declining, is still a key factor in generating activities for other sectors of the economy such as services and industries. Contribution of the agricultural sector and businesses accounted for $27 \%$ of the GDP (Ministry of Agriculture, The National Strategy, 2006).

In addition to the economic role of the agricultural sector, its social role lies in limiting migration from rural to urban areas. Agriculture being the core of Jordan's rural area development is the main source of income for its inhabitants; and creates job opportunities and income generating activities in agriculture and related agribusiness activities. The number of employed agricultural labor increased from 68,000 in $1996(31 \%$ Jordanians) to about 114,000 in 2000 (55\% Jordanians).

Permanent agricultural labor is mainly concentrated in the Jordan Valley areas, where it constitutes $60 \%$ of the total labor in the Jordan Valley compared to only $9 \%$ in the Highlands (Ministry of Agriculture, The National Strategy, 2000). Agriculture has an important environmental role to play in conserving the biodiversity of natural vegetation, soil, water, flora, and fauna. The significance of this role is related to its major contributions in reducing the threats of both desertification, degradation of the environment, land, water resources, and reducing biodiversity.

Exports of the most important vegetable crops during 2007 generated 143.1 million JDs, of which the value of vegetable exports from the Jordan Valley reached about 61.53 million JD's (Ministry of Agriculture, The national Strategy, 2007). Of the total area of about 4 million donums, $11 \%$ of it is cultivated with irrigated vegetables. The area of the irrigated land in the Jordan Valley accounted for 180141.1 donums or $43 \%$ of the total irrigated land in the Kingdom of Jordan (Department of Statistics, 2006).

Uncertainty is said to exist where one or both, of two issues exist for a management decision. All of the outcomes are unknown, the probabilities of the outcomes are unknown, or neither the outcome nor the probabilities are known (Kay, 1981). Risk is associated with variability - the more variable the expected outcome of a decision, the riskier the decision.

The degree of uncertainty can be defined and measured as the forecaster's "probability distribution" the probability estimates associated with each possible outcome. In its simplest form, a probability distribution could consist of simply a potential outcome. For example, in forecasting profits, an optimistic estimate, a pessimistic estimate, and a most likely estimate could be made. Or alternatively, high, low, and the best guess estimates could be made. This notation of risk is conveyed by the observation that the higher the probability distribution of expected future returns, the smaller the risk of a given project. Standard deviation $(\sigma)$ is used as a measure of the tightness of the probability distribution of project returns.

Because of the high risk associated with wide fluctuations in returns and high input prices, the vegetables farmers in Jordan Valley are forced to minimize risk 
by limiting themselves to only the most important inputs of production. As a result of this, the adoption rate of vegetable technology in the Jordan Valley can be increased. Also, risk and uncertainty contribute to discrepancies in the rates of adoption by vegetable farmers. Among the other impacts of uncertainty are the farm sizes being limited to uncertainty, which does not ensure a reasonable standard of living and consequently creates disguised unemployment. Uncertainty also affects the portion of the use of production inputs in using more labor than other production inputs. Farmers prefer to use less quantities of capital than they should to maximize profits. They prefer to have cash (money) reserves for when they face bad conditions (capital rationing). Uncertainty leads to short-run investment rather than long-run investment. It also causes credit agencies to raise the capital interest on agricultural loans and limits the amounts of such loans, making it more difficult for the farmer to obtain a loan.

The study of risk and uncertainty is very important in understanding farmers' decision making process. The farmers' attitudes towards risk are considered the main constraints to the adoption rates of vegetable technology by them and to the rural development program. To make the adoption of technology and the development program very efficient, special attention should be paid to the attitudes of various groups of farmers towards risk. It is therefore important to identify the farmers, and their constraining attitudes towards risk and to point out their impact on the decision making process.

\section{The problem statement}

The variability in production and yields of vegetables and the uncertainty about returns are the main problems in the vegetable sector in Jordan. This is attributed to, among other factors, uncertainty.

Uncertainty about yield varies, because invariably some input variables are beyond the decision maker's control, and their levels are unknown at the time decisions have to be made about the controlled input variables. Consider a "timeless" response function which includes all the non-fixed input variables $\mathrm{X}_{1}, \mathrm{X}_{2}, \ldots, \mathrm{X}_{\mathrm{m}}$ that influence yield. The complete response function can be written as follows:

$\mathrm{Y}=\mathrm{f}\left(\mathrm{X}_{1}, \ldots \mathrm{X}_{\mathrm{n}} ; \mathrm{X}_{\mathrm{n}+1}, \ldots . \mathrm{X}_{\mathrm{k}} ; \mathrm{X}_{\mathrm{k}+1}, \ldots .\right.$. $\left.X_{m}\right)$

The following describes the three groups of input factors:

- $\quad \mathrm{X}_{1}, \mathrm{X}_{2}, \ldots, \mathrm{X}_{\mathrm{n}}$ denote variables whose levels are uncontrolled by the decision maker; these are the "decision variables". Typical controlled variables in crop production are fertilizers, seed quantity, crop variety, herbicides, and insecticides.

- $\quad X_{n+1}, X_{n+2}, \ldots \ldots, X_{k}$ denote variables whose levels are uncontrolled but are known to the decision maker at the time he/she has to decide on the decision variables; these are the "predetermined variables". Examples of these are initial soil fertility and soil moisture content.

- $\quad \mathrm{X}_{\mathrm{k}}, \mathrm{X}_{\mathrm{k}+1}, \ldots . ., \mathrm{X}_{\mathrm{m}}$ denote variables whose levels are neither controlled by nor known to the decision maker at the time he/she chooses levels for the controlled inputs; these are "uncertain variables." The major uncertain (uncontrolled and unknown) inputs are climatic variables such as rainfall, temperature, wind, solar radiation, etc. Yield uncertainty arises from the influence of the uncontrolled variables $X_{k+1}, \ldots \ldots, X_{m}$ whose levels are unknown. Since the input values $X_{k+1}$, ....., $X_{m}$ are unknown, the yield to be obtained can not be assured. However, a subjective probability distribution for 
yield, in relation to possible combinations of levels of the uncertain input variables, can be specified.

\section{Objectives of the Study}

The main objective of the study is to examine the vegetable farmers' attitudes towards risk in the Jordan Valley. Specific objectives of the study are to estimate utility functions for measuring vegetable farmers' risk attitudes in the Jordan Valley; and to examine the relationship between vegetable farmers' personal characteristics such as age, education, farm size, family size, and experience in agriculture, and their attitudes towards risk.

\section{Theoretical Framework and Literature Review}

Increasingly, the concept of risk is becoming more important in the decision making process of agricultural production and resource allocation. In relevant literature, the concepts of risk include measure of dispersion, variance or standard deviation; and "chance of loss" being the probability $(\mathrm{X})$ associated with random income (B) falling below some disaster level (d). This is defined by the equation: $\operatorname{Pr}(\mathrm{B}<\mathrm{d})=\mathrm{X}$.

Since this research focuses on risky decisions on the use of resources in the context of expected utility maximization, the first concept, as a method of risk is used in the analysis. This implies the application of Bernoulli's principle or the Expected Utility theorem. The Bernoulli principle uses two key elements, namely the personal valuation of consequence (utility terms) and the personal strength of belief about the uncertain events (subjective probability). The Bernoulli principle follows from the following postulates:

Ordering: for the two alternatives A and $\mathrm{B}$, one of following must be true: the individual prefers $\mathrm{A}$ to $\mathrm{B}$ or he prefers $\mathrm{B}$ to $\mathrm{A}$, or he is indifferent to them.
Transitivity: the individual's evaluation of alternatives is transitive; if he prefers $\mathrm{A}$ to $\mathrm{B}$ and $\mathrm{B}$ to $\mathrm{C}$, then he prefers $\mathrm{A}$ to C.

Continuity: Assume that A is preferred to $\mathrm{B}$ and $\mathrm{B}$ to $\mathrm{C}$. The axiom asserts that there exists some probability $\mathrm{P}(0<\mathrm{P}<$ $1)$, such that the individual is indifferent to the outcome B with certainty, and a lottery ticket offering the outcome A and $\mathrm{C}$ with probabilities $\mathrm{P}$ and (1-P), respectively.

Independence: Assume that the individual is preferred $\mathrm{A}$ and $\mathrm{B}$, and $\mathrm{C}$ is any outcome. If one lottery ticket results in outcome A and C, P and (1-P) respectively, and another outcome offer $\mathrm{B}$ and $\mathrm{C}$ with the same probabilities $\mathrm{P}$ and (1-P), the individual is indifferent to the two lottery tickets. If these postulates are not violated, then it is possible to derive utility functions.

Von Neumann and Morgenstern (1947) are major contributors to a large body of work that provides justification for the use of the expected utility model by a rational decision maker. This model views decision making under circumstances of risk as a choice between alternatives. Decision makers are assumed to have a preference ordering defined over the probability distributions for which the axioms of the expected utility model hold.

Officer and Halter (1968) derived utility functions for wool producers in northern New South Wales, Australia. They used three models of utility estimation, namely the Von NeumannMorgenstern, the modified Von Neumann-Morgenstern, and the Ramsey. The study tested the hypothesis that maximizing expected utility, as a criterion for decision, is superior to maximizing expected monetary values. The results indicated that the Ramsey model was superior to the Von NeumannMorgenstern models. Lin, Dean and 
Moore (1974) provided an empirical test for utility vs. profit maximization in agricultural production in California. Utility and profit maximization crops and plans were determined for six large California farms. The results of the study supported the hypothesis that Bernoullian utility is a more accurate predictor of farmer behavior than profit maximization.

Moscardi and de Janvry (1977) examined attitudes towards risk among peasants in Puebla, Mexico. An econometric approach was used in the analysis. Results of the study indicated that estimation of risk aversion, following the indirect method outlined in the analysis (safety first behavior), shows that risk aversion is indeed responsible for substantial differences between the demand for fertilizer without risk and actual demand. Risk premiums were high, discouraging the use of high rates of fertilizer.

Halter and Mason (1978) estimated decision makers' utility functions for the measurement of farmers' risk attitudes. A practical technique for estimating farmers' utility functions and regression analysis were used in the study. The results of the study indicated that the farmers' characteristics such as age, education, and percentage of land ownership were statistically significant variables related to risk attitudes.

Binswanger (1981) measured attitude towards risk in rural India. His approach is embedded in the expected utility theory. He measured risk attitudes to a set of real payments. Real money payments may result in incentive effects and may not reveal the true risk preference of farmers. Schubert et al. (2000) studied the gender specific attitudes towards risk and ambiguity. On one hand, empirical evidence shows that in financial markets women's behavior is more risk averse than men. On the other hand, there is experimental data showing that in risky decisions controlled for opportunity sets, only the context matters. In investment and insurance contexts women, seem to display the same risk aversion as men. They found that women are more ambiguously averse than men in the investment context, but not in the insurance context.

Holt and Laury (2002) used a menu of ordered lottery choices to make inferences about risk aversion under various payment conditions. The main results showed that the subjects were risk adverse, risk aversion increases sharply with large increases in the scale of cash payoffs, and there was no significant effect from increasing the scale of hypothetical payment. Harrison et al. (2003) designed experiments to jointly elicit risk and time preferences for the adult Danish population. They used field experiments and examined the characterization of risk over a wider domain allowing more precise estimates of risk attitudes. Risk and time preferences were therefore found to be heterogeneous. Anderson et al. (2004) examined the strengths and weaknesses of lab and field experiments to detect differences in preferences that are associated with standard, observable characteristics of the individual. Their results provide evidence that there are good reasons to conduct field experiments. Humphrey and Verschoor (2004) used an experiment to test individual decision making behavior under risk in rural east Uganda. They used in eight of the twelve decision problems real money payments. However, all choice problems were considered as if they were being played for real money. They found that the risk preferences of east Ugandan farmers exhibit systematic and predictable deviations from expected utility maximization. They also found evidence of a substantial stochastic component to behavior.

Dohmen et al. (2005) present new evidence on the distribution of risk 
attitudes in the population using a novel set of survey questions and a representative sample of roughly 22,000 individuals living in Germany. Using a questionaire that asks about the individuals' willingness to take risk on an 11 point scale, they found evidence of heterogeneity across individuals, that showed willingness to take risks is negatively related to age and being female positively related to height and parental education. They also used more standard lottery questions to measure risk preferences which made it possible to estimate the coefficient of relative risk aversion for the individuals in the sample. Harrison et al. (2006) examined individual risk attitudes using controlled experiments in the field in Denmark. These risk preferences were elicited by means of field experiments involving real monetary rewards. They used a representative sample of 253 people between 19 and 75 years of age. Their results indicated that the average Dane is risk averse, and the risk neutrality is an inappropriate assumption to apply. They also found that risk attitudes vary significantly with respect to several important socio-demographic variables such as age and education. However, they did not find any effect of difference in sex on risk attitudes.

Haile et al. (2007) conducted a test on 199 farmers in two different districts in Tigray, Northern Ethiopia. Two items were central in comparing the risk attitude according to the expected utility (EU) and prospect theory (PT). The farmers in two different districts (Enderta and Hintalo-Wajerat) differed significantly in their risk attitude. Enderta farmers were significantly risk-averse for gains and risk-seeking for losses, and their preferences conformed to the hypothesis of prospect theory. However, expected utility maximization was found to be an appropriate descriptor for Hintalo-Wajerat farmers.
Yesuf et al. (2009) studied poverty, risk aversion, and path dependence in low income countries and presented experimental evidence from Ethiopia. Their paper estimated levels and determinants of risk aversion in the highlands of Ethiopia. The findings showed that there was high risk aversion and that constraints have an important impact on risk averting behavior with significant implications for long term poverty.

\section{Experimental Data}

The data used to analyze the vegetable farmers' attitudes towards risk in the Jordan Valley were obtained by personal interviews conducted during the vegetable season of 2007-2008, in addition to secondary data from the Jordanian Department of Statistics and the Ministry of Agriculture necessary to this study. The respondents were contacted personally and visited on farms by well trained interviewers.

A random sample of 200 vegetable farmers was selected and interviewed.

The sample size of 200 vegetable farmers was determined using the following formula (Dominick, 1982) where $\mathrm{N}$ is an unknown population:

$\mathrm{N}=\mathrm{p} * \mathrm{q}\left(\mathrm{z}_{\mathrm{x}} / \mathrm{e}\right)^{2}$

Where,

$\mathrm{n}=$ sample size

$\mathrm{P}=$ successes in the proportion of the population

$(1-\mathrm{P})=$ failure in the proportion of the population

$\mathrm{Zx} / 2=1.845$ ( $\mathrm{Z}$-value used in a $93.349 \%$ confidence interval)

$\mathrm{e}=$ degree of error $(6.51 \%)$

Therefore, with $\mathrm{p}=0.50$ and $(1-\mathrm{p})=0.50$ $\mathrm{n}=0.50 * 0.50(1.845 / 0.0651)^{2}=200$

To accomplish the two objectives of the study, a purpose sample of 50 vegetable farmers, from the main sample of 200 farmers, was selected. This small 
sample size was chosen because the techniques used to estimate utility functions require some understanding and a certain level of education, which most of the farmers did not possess. There was no problem with the Von NeumannMorgenstern method, because the respondents understood the concept of probabilities. In the small selective sample of 50 agricultural engineers, some of them were MSc degree holders.

Von Neumann-Morgenstern model is based on a concept called standard reference contract. Two alternatives, Alternative $\mathrm{A}$ and Alternative $\mathrm{B}$ are considered. Alternative A represents the probability $\mathrm{P}$ of winning, for example,

J. D. 1000 and probability (1-P) of losing J. D. 1000. Alternative B, on the other hand represents a certain amount of cash. Different probability levels are assumed by considering the gains and losses of a certain range (e. g.-1000 to 1000 J. D.) to obtain the indifference points between having a certain amount of money (certain cash) and risk taking. Appendix A illustrates the Von NeumannMorgenstern model.

\section{Results}

Using the Von NeumannMorgenstern model, the quadratic utility functions for 50 vegetable farmers in the Jordan Valley were estimated. The risk attitude coefficient for each farmer was then estimated. The risk attitude coefficient is defined as the negative ratio of the second to the first derivative of the utility function evaluated at the 20072008 farmer's gross income level. This is called the Pratt- coefficient, named after its founder, and it can be compared with individuals, whereas the individual utility functions cannot be so compared.

The 50 utility functions were evaluated for the Pratt coefficient at the decision maker's gross income level and classified by the sign of the coefficient into risk averse, risk neutral, and risk preference. It was found that 13 farmers $(26 \%), 15$ farmers $(30 \%)$, and 22 farmers (44\%) were falling into the risk averse, risk neutral, and risk preference categories, respectively.

Therefore, $44 \%$ of farmers in the Jordan Valley are risk takers, because $100 \%$ of their income is from irrigated agriculture, they have large investments and high technology. Table 1 displays the results of the utility functions estimation and Figure1 shows three of the utility functions estimated from the sample.

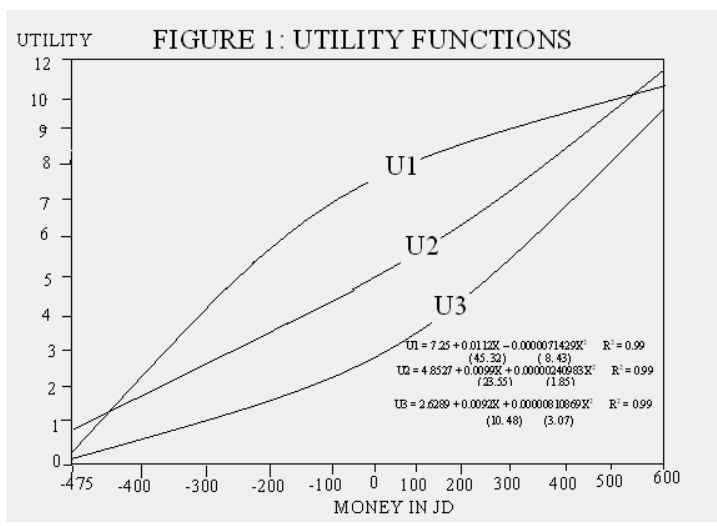

The risk coefficient was taken as the dependent variable and the farmers' characteristics were taken as independent variables, which were age, educational level, family size, farm size, and experience in agriculture.

By using the linear equation, the coefficient of experience in agriculture (X4) was statistically significant at $5 \%$ of the significance level. The following is the estimated equation:

$\mathrm{Y}^{\wedge}=0.133-0.002358 \mathrm{X}_{1}+0.002237 \mathrm{X}_{2}$ $-0.000165 \mathrm{X}_{3}+0.004295 \mathrm{X}_{4}-0.00414$ $\mathrm{X}_{5}$
t- Values (1.87) (-1.146)
$0.6817) \quad(-1.0226)$
$(-0.7881)$

Where

$\mathrm{Y}=$ risk-coefficient

$\mathrm{X}_{1}=$ age in years

$\mathrm{X}_{2}=$ education level in years

$\mathrm{X}_{3}=$ farm size in donums

$\mathrm{X}_{4}=$ experience in agriculture in years

$\mathrm{X}_{5}=$ family size in number of members 
Table 1. The Farmers' Utility Functions.

\begin{tabular}{|c|c|c|c|}
\hline Farmer No. & Utility Function & $R^{2} 100 \%$ & Risk Coefficient* \\
\hline 1 & $\mathrm{U}(\mathrm{X})=5+.005 \mathrm{X}^{* *}-0.0000000 \mathrm{X}^{2}$ & 100.0 & 0.00000 \\
\hline 2 & $\mathrm{U}(\mathrm{X})=7.73566+0.0096550 \mathrm{X}-0.0000109 \mathrm{X}^{2}$ & 98.8 & +0.05291 \\
\hline 3 & $\mathrm{U}(\mathrm{X})=7.80735+0.0084256 \mathrm{X}-0.0000088 \mathrm{X}^{2}$ & 94.8 & +0.00458 \\
\hline 4 & $\mathrm{U}(\mathrm{X})=8.19639+0.0100018 \mathrm{X}-0.0000129 \mathrm{X}^{2}$ & 99.8 & +0.0265 \\
\hline 5 & $\mathrm{U}(\mathrm{X})=5+0.005 \mathrm{X}-0.000000 \mathrm{X}^{2}$ & 100.0 & 0.00000 \\
\hline 6 & $\mathrm{U}(\mathrm{X})=2.75829+0.0097190 \mathrm{X}+0.0000086 \mathrm{X}^{2}$ & 99.6 & -0.00063 \\
\hline 7 & $\mathrm{U}(\mathrm{X})=7.24171+0.0097190 \mathrm{X}-0.0000086 \mathrm{X}^{2}$ & 99.6 & +0.066 \\
\hline 8 & $\mathrm{U}(\mathrm{X})=5+0.005 \mathrm{X}-0.000000 \mathrm{X}^{2}$ & 100.0 & 0.00000 \\
\hline 9 & $\mathrm{U}(\mathrm{X})=5+0.005 \mathrm{X}-0.000000 \mathrm{X}^{2}$ & 100.0 & 0.00000 \\
\hline 10 & $\mathrm{U}(\mathrm{X})=3.05978+0.0094190 \mathrm{X}+0.0000075 \mathrm{X}^{2}$ & 98.9 & -0.000614 \\
\hline 11 & $\mathrm{U}(\mathrm{X})=6.15606+0.0097285 \mathrm{X}-0.0000041 \mathrm{X}^{2}$ & 99.6 & +0.012 \\
\hline 12 & $\mathrm{U}(\mathrm{X})=1.80361+0.0100018 \mathrm{X}+0.0000129 \mathrm{X}^{2}$ & 99.8 & -0.00072 \\
\hline 13 & $\mathrm{U}(\mathrm{X})=5+0.005 \mathrm{X}-0.000000 \mathrm{X}^{2}$ & 100.0 & 0.00000 \\
\hline 14 & $\mathrm{U}(\mathrm{X})=7.26484+0.0050104 \mathrm{X}-0.0000022 \mathrm{X}^{2}$ & 99.8 & +0.11458 \\
\hline 15 & $\mathrm{U}(\mathrm{X})=6.47292+0.0049642 \mathrm{X}-0.0000014 \mathrm{X}^{2}$ & 98.8 & +0.34146 \\
\hline 16 & $\mathrm{U}(\mathrm{X})=2.58538+0.0047253 \mathrm{X}+0.0000022 \mathrm{X}^{2}$ & 98.8 & -0.00048 \\
\hline 17 & $\mathrm{U}(\mathrm{X})=5+0.005 \mathrm{X}-0.000000 \mathrm{X}^{2}$ & 100.0 & 0.00000 \\
\hline 18 & $\mathrm{U}(\mathrm{X})=0.674460+0.0048039 \mathrm{X}+0.0000042 \mathrm{X}^{2}$ & 99.5 & -0.0005 \\
\hline 19 & $\mathrm{U}(\mathrm{X})=1.67413+0.0046730 \mathrm{X}+0.0000031 \mathrm{X}^{2}$ & 98.9 & -0.00057 \\
\hline 20 & $\mathrm{U}(\mathrm{X})=6.52918+0.0046393 \mathrm{X}-0.0000013 \mathrm{X}^{2}$ & 98.7 & +0.23008 \\
\hline 21 & $\mathrm{U}(\mathrm{X})=5+0.005 \mathrm{X}-0.000000 \mathrm{X}^{2}$ & 100.0 & 0.00000 \\
\hline 22 & $\mathrm{U}(\mathrm{X})=6.82829+0.0046112 \mathrm{X}-0.0000015 \mathrm{X}^{2}$ & 98.3 & +0.14150 \\
\hline 23 & $\mathrm{U}(\mathrm{X})=-0.329857+0.0041507 \mathrm{X}+0.0000045 \mathrm{X}^{2}$ & 92.7 & -0.00068 \\
\hline 24 & $\mathrm{U}(\mathrm{X})=5+0.005 \mathrm{X}-0.000000 \mathrm{X}^{2}$ & 100.0 & 0.00000 \\
\hline 25 & $\mathrm{U} \mid(\mathrm{X})=7.07868+0.0049522 \mathrm{X}-0.0000020 \mathrm{X}^{2}$ & 99.9 & +0.12422 \\
\hline 26 & $\mathrm{U}(\mathrm{X})=2.50175+0.0050138 \mathrm{X}+0.0000025 \mathrm{X}^{2}$ & 99.7 & -0.00049 \\
\hline 27 & $\mathrm{U}(\mathrm{X})=5+0.005 \mathrm{X}-0.000000 \mathrm{X}^{2}$ & 100.0 & 0.00000 \\
\hline 28 & $\mathrm{U}(\mathrm{X})=-1.07887+0.0042235 \mathrm{X}+0.0000053 \mathrm{X}^{2}$ & 94.1 & -0.00071 \\
\hline 29 & $\mathrm{U}(\mathrm{X})=0.359015+0.0047510 \mathrm{X}+0.0000044 \mathrm{X}^{2}$ & 98.3 & -0.00064 \\
\hline 30 & $\mathrm{U}(\mathrm{X})=5+0.005 \mathrm{X}-0.000000 \mathrm{X}^{2}$ & 100.0 & 0.00000 \\
\hline 31 & $\mathrm{U}(\mathrm{X})=7.07868+0.0049522 \mathrm{X}-0.0000020 \mathrm{X}^{2}$ & 99.9 & +0.12422 \\
\hline 32 & $\mathrm{U}(\mathrm{X})=-0.664250+0.0046117 \mathrm{X}+0.0000053 \mathrm{X}^{2}$ & 96.0 & -0.000696 \\
\hline 33 & $\mathrm{U}(\mathrm{X})=5+0.005 \mathrm{X}-0.000000 \mathrm{X}^{2}$ & 100.0 & 0.00000 \\
\hline 34 & $\mathrm{U}(\mathrm{X})=0.230201+0.0046002 \mathrm{X}+0.0000044 \mathrm{X}^{2}$ & 97.3 & -0.000656 \\
\hline 35 & $\mathrm{U}(\mathrm{X})=5+0.005 \mathrm{X}-0.000000 \mathrm{X}^{2}$ & 100.0 & 0.00000 \\
\hline 36 & $\mathrm{U}(\mathrm{X})=7.94606+0.0049157 \mathrm{X}-0.0000029 \mathrm{X}^{2}$ & 99.4 & +0.13272 \\
\hline 37 & $\mathrm{U}(\mathrm{X})=-0.354724+0.0047058 \mathrm{X}+0.0000051 \mathrm{X}^{2}$ & 98.5 & -0.00068 \\
\hline 38 & $\mathrm{U}(\mathrm{X})=1.38370+0.0047394 \mathrm{X}+0.0000034 \mathrm{X}^{2}$ & 99.2 & -0.00005 \\
\hline 39 & $\mathrm{U}(\mathrm{X})=5+0.005 \mathrm{X}-0.000000 \mathrm{X}^{2}$ & 100.0 & 0.00000 \\
\hline 40 & $\mathrm{U}(\mathrm{X})=1.60793+0.0044037 \mathrm{X}+0.0000030 \mathrm{X}^{2}$ & 95.6 & -0.00057 \\
\hline 41 & $\mathrm{U}(\mathrm{X})=1.82006+0.0050623 \mathrm{X}+0.0000032 \mathrm{X}^{2}$ & 99.6 & -0.00055 \\
\hline 42 & $\mathrm{U}(\mathrm{X})=2.33469+0.0047311 \mathrm{X}+0.0000024 \mathrm{X}^{2}$ & 99.2 & -0.00050 \\
\hline 43 & $\mathrm{U}(\mathrm{X})=1.78355+0.0040728 \mathrm{X}+0.0000024 \mathrm{X}^{2}$ & 92.0 & -0.00054 \\
\hline 44 & $\mathrm{U}(\mathrm{X})=5+0.005 \mathrm{X}-0.000000 \mathrm{X}^{2}$ & 100.0 & 0.00000 \\
\hline 45 & $\mathrm{U}(\mathrm{X})=7.23365+0.0048020 \mathrm{X}-0.0000020 \mathrm{X}^{2}$ & 98.7 & +0.28571 \\
\hline 46 & $\mathrm{U}(\mathrm{X})=0.471886+0.0043447 \mathrm{X}+0.0000039 \mathrm{X}^{2}$ & 95.9 & -0.00064 \\
\hline 47 & $\mathrm{U}(\mathrm{X})=5+0.005 \mathrm{X}-0.000000 \mathrm{X}^{2}$ & 100.0 & 0.00000 \\
\hline 48 & $\mathrm{U}(\mathrm{X})=3.16314+0.0047484 \mathrm{X}+0.0000016 \mathrm{X}^{2}$ & 98.6 & -0.00040 \\
\hline 49 & $\mathrm{U}(\mathrm{X})=0.997143+0.0045614 \mathrm{X}+0.0000036 \mathrm{X}^{2}$ & 97.3 & -0.00061 \\
\hline 50 & $\mathrm{U}(\mathrm{X})=1.97146+0.0046731 \mathrm{X}+0.0000027 \mathrm{X}^{2}$ & 98.5 & -0.00053 \\
\hline
\end{tabular}

$*$ Negative sign $(-)=$ risk preference $;$ Positive sign $(+)=$ risk averse ; Zero $(0)=$ risk neutral .

** $\mathrm{X}=$ money in J.D ( Jordanian Diner $)$.

The linear equation was transformed into semi-log (only the dependent variable), the risk coefficient was transformed into log by using the same independent variables, namely age $\left(\mathrm{X}_{1}\right)$, educational level $\left(\mathrm{X}_{2}\right)$, farm size $\left(\mathrm{X}_{3}\right)$, 
experience in agriculture $\left(\mathrm{X}_{4}\right)$, and family size $\left(\mathrm{X}_{5}\right)$. The following is the estimated equation:

Lin $\mathrm{y}^{\wedge}=1.7862-0.0564 \mathrm{X}_{1}+0.1599 \mathrm{X}_{2}$ $+0.01546 \mathrm{X}_{3}-0.0966 \mathrm{X}_{4}+0.4685 \mathrm{X}_{5}$
t-values $\quad(0.5562)$
$(-\quad 0.6075)$
(1.0791)
(2.1264)
$(-1.1031)$

(1.9732)

By transforming the linear equation into a semi-log equation, the coefficient of farm size $\left(\mathrm{X}_{3}\right)$ and the coefficient of family size $\left(\mathrm{X}_{5}\right)$ were statistically significant at $5 \%$ of the significance level.

By transforming the linear equation into a double-log equation, the following was found to be the estimated equation:

$\operatorname{Ln} \mathrm{Y}^{\wedge}=9.1773-4.1461 \ln \mathrm{X}_{1}+1.0165 \ln$ $\mathrm{X}_{2}+1.6334 \ln \mathrm{X}_{3}-0.9622 \ln \mathrm{X}_{4}+$ $2.0988 \ln \mathrm{X}_{5}$
t-values
(0.90609)
(1.8946)

(1.8041)

The coefficient of farm size $\left(\mathrm{X}_{3}\right)$ and the coefficient of family size $\left(\mathrm{X}_{5}\right)$ were statistically significant at $6 \%$ and $7 \%$ of the significance level. The signs of the coefficients coincide with the economic theory.

\section{Summary and Conclusions}

The main objective of the study was to examine the vegetable farmers' attitudes towards risk in the Jordan Valley. The data used to analyze the farmers' attitudes towards risk were collected through personal interviews, in addition to secondary data necessary in this study. For the measurement and explanation of the risk attitudes of vegetable farmers in the Jordan Valley, utility functions for a purpose sample of 50 vegetable farmers were estimated.

For estimating these utility functions the Von Neumann-Morgenstern model was used and the risk attitude coefficient (Pratt coefficient) for each farmer was estimated.
The results of the study indicated that 13 vegetables farmers $(26 \%), 15$ farmers $(30 \%)$, and 22 farmers $(44 \%)$ fell into the categories of risk averse, risk neutral, and risk preference, respectively.

Studying farmers' attitudes towards risk is very important in the decision making process and the attitudes are considered the main constraints to the adoption rates of vegetable technology by farmers, and consequently, vegetable production is affected by these attitudes. About $44 \%$ of the sample farmers are risk preferrers and their whole income is from agriculture.

The high percentage of risk preference of the sample farmers was consistent with the farmers' attitudes and practices. A multiple linear regression model was used to examine the relationship between the farmers' personal characteristics such as age, education, farm size, family size and experience in agriculture, and their risk attitudes. The risk coefficient was taken as the dependent variable and the farmers' characteristics were taken as independent variables (i.e. age, educational level, farm size, experience in agriculture, and family size.) The regression results of the study indicated that the coefficient of farm size $\left(\mathrm{X}_{3}\right)$ and the coefficient of family size $\left(\mathrm{X}_{5}\right)$ were statistically significant at $5 \%$ of the significance level.

Polynomial functions can be fitted to the points by ordinary least squares (QLS) in order to determine and illustrate different types of utility functions for different individuals. From the estimated utility functions we can obtain the Pratt coefficient, a measure of risk attitude that is defined as the negative ratio of the second to the first derivative of the utility function evaluated at money gains or at the respondent's (farmer) net income level. We can take the Pratt coefficient as the dependent variable and run a regression to determine if there is a relationship between the risk attitude (Pratt-coefficient) and other explanatory 
variables, such as education, farm size, age, family size, and experience in agriculture.

\section{Acknowledgment}

This research project was carried out during the Researcher's sabbatical leave for the 2007-2008 academic year. It was funded by the Deanship of Academic Research, University of Jordan, Amman, Jordan.

\section{References}

Andersen, S., G. W. Harrison, M. I. Lau and E. E. Rutstroem. 2004. Preference Heterogeneity in Experiments: Comparing the Field and Lab. Center for Economic and Business Research, Copenhagen, Denmark (Andersen and Lau) and Department of Economics, College of Business Administration, University of Central Florida, U.S.A. (Harrison and Rutstroem).

Binswanger, H. 1981. Attitude Toward Risk: Theoretical Implications of an Experiment in Rural India. Economic Journal. 91:867-890.

Statistical Yearbook. 1992. Department of Statistics, Amman, Jordan.

Statistical Yearbook. 2000. Department of Statistics, Amman, Jordan.

Statistical Yearbook. 2006. Department of Statistics, Amman, Jordan.

Dohmen, T., A. Falk, D. Huffman, U. Sunde, J. Schupp and G. Wagner. 2005. Individual Risk Attitudes: New Evidence From a Large Representative, ExperimentallyValidated Survey, Discussion Paper 1730, Institute for the Study of Labor, Bonn, Germany.
Dominick, S. 1982. Schaum's Outline of Theory and Problems of Statistics and Econometrics. McGraw - Hall Book Company. 74-75.

Haile, N., A. Oskam and J. Peerlings. 2007. Decision-Making Under Risk: Evidence From Nothern Ethiopia, Wageningen University and Research, Agricultural Economics and Rural Policy Group. Hollandsweg1, $6706 \quad$ KN Wageningen, The Netherlands. Tigray Food Security Coordination Office, KfW-SUN Program, Mekelle.

Halter, A. N. and R. Mason. 1978. Utility Measurement and Managerial Behavior. J. Farm Econ. 42:118-132.

Holt, C. A. and S. Laury. 2002. Risk Aversion and Incentive Effects, American Economic Review. 92(5):1644-1655.

Hamphrey, S., and A. Verschoor. 2004. Decision-Making under Risk Among Small Farmers in East Uganda. Journal of African Economies 13(1):44-101.

Harrison, G. W., M. I. Lau, E. E. Rutstroem and M. B. Williams. 2003. Eliciting Risk and Time Preferences Using Field Experiments:Some Methodological Issues. Department of Economics, College of Business Administration, University of Central Florida, U.S.A. (Harrison and Rutstroem), Center for Economic and Business Research, Copenhagen, Denmark (Lau), and National Center for Environmental Economics, U.S. Environmental Protection Agency (Williams).

Harrison, G. W, M. I. Lau and E. E. Rutstroem. 2006. Estimating Risk Attitudes In Denmark: A Field Experiment. Department of 
Emir. J. Food Agric. 2009. 21 (2): 51-63

http://cfa.uaeu.ac.ae/ejfa.shtml

Economics, College of Business Administration, University of Central Florida, U.S.A. (Harrison and Rutstroem), and Department of Economics and Finance, Durham Business School, Durham University, United Kingdom (Lau).

Kay, Ronald D. 1981. Farm Management Planning, Control, and Implementation, McGraw-Hill Book Company, New York, 335-336.

Lin, W., G. Dean, and C. Moore. 1974. An Empirical Test of Utility vs. Profit Maximization in Agricultural Production, Am. J. Agric. Econ. 56:497-508.

The National Strategy. 2000. Ministry of Agriculture, Amman, Jordan.

The National Strategy. 2006. Ministry of Agriculture, Amman, Jordan.

The National Strategy. 2007. Ministry of Agriculture, Amman, Jordan.
Moscardi, E., and A. de Janvry. 1977. Attitudes toward Risk among Peasants: An Econometric Approach. Am. J. Agric. Econ. 59:710-716.

Neumann, Von J. and O. Morgenstern. 1944. The Theory of Games and Economic Behavior. Princeton: Princeton University Press.

Officer, R. R. and A. H. Halter. 1968. Utility Analysis in a Practical Setting, Am. J. Agric. Econ. 50:257-277.

Schubert, R., M. Gysler, M. Brown, and H. W. Brachinger. 2000. Gender Specific Attitudes Towards Risk and Ambiguity: An Experimental Investigation. Center for Economic Research, Swiss Federal Institute of Technology, CH-8092 Zuerich. Seminar of Statistics, University of Fribourg, CH-1700 Fribourg.

Yesuf, M. et al., 2009. Poverty, Risk Aversion and Path Dependence in Low Income Countries: Experimental evidence from Ethiopia. JEL Classifications: C93; D81; Q12; Q21. 


\section{Appendix A.}

Von Neumann-Morgenstern Model for Estimating Utility Functions

This model is based on a concept called standard reference contract. Two alternatives are considered:

Alternative A: Probability $\mathrm{P}$ of winning J. D. 1000 and probability (1-P) of losing J. D. 1000.

Alternative B: Given amount of cash for certain (certain cash)

The following probabilities for $\mathrm{P}$ are assumed: $\mathrm{P}=1.0 ; \mathrm{P}=0.8 ; \mathrm{P}=0.6 ; \mathrm{P}=$ $0.4 ; \mathrm{P}=0.2 ; \mathrm{P}=0.0$. The gains and losses are considered over the range of $-1000 \mathrm{~J}$. $\mathrm{D}$ to $1000 \mathrm{~J}$. D. in order to obtain the indifference points between having a certain amount of money (certain cash) and risk taking.

The decision maker (the farmer) is asked to indicate his preference between $A$ and $B$ for a series of different values of $P$ and levels of "certain cash". This process can be clarified by considering Table 2. Alternative B (certain cash) is listed in the left-hand column. Alternative A, providing either J. D.1000 with probability $\mathrm{P}$ or - J. D. 1000 with probability (1-P), is listed across the top. The decision maker is then asked to indicate, for each cell in each column, whether he prefers $\mathrm{A}$ or $\mathrm{B}$, or is indifferent. For example, start from the bottom of the first column of the Table 2 . Do you prefer J. D. 1100 certain cash (B) or a preference contract (A) with probability 1.0 of winning J. D. 1000 and probability 0 of losing J. D. 1000. Alternative B is obviously preferred. Moving up to the next cell, ask a similar question: Do you prefer J. D.1000 certain cash (B), or a reference contract (A) with probability 1.0 of winning J. D. 1000 or probability 0 of losing J. D. 1000. These alternatives are obviously identical and we write "indifferent". Moving up to the next cell and asking a similar question, we find that $\mathrm{A}$ is clearly preferred and likewise for all cells in the remainder of the first column. The remainder of Table 2 is filled out in similar fashion. The indifference points obtained can be used to graph utility functions after associating utilities to each indifference point (Figure 2).

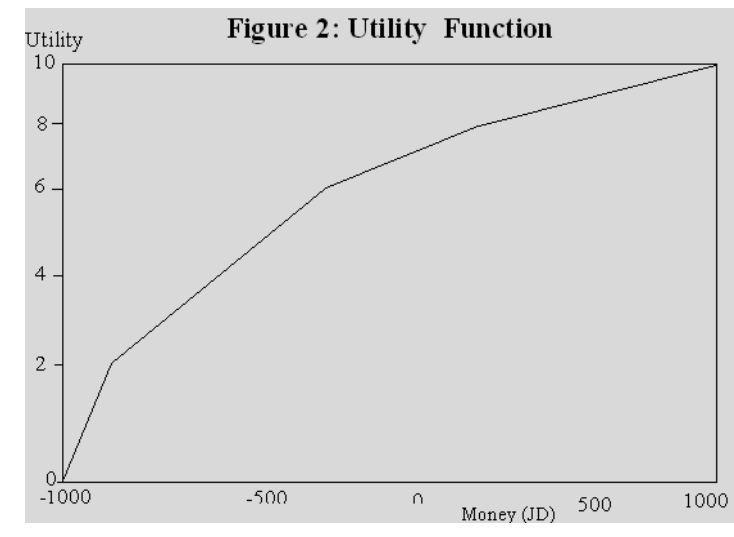

We define $U$ (-1000J. D.) $=0$ and $U$ $(1000 \mathrm{~J}$. D. $)=10$ as an arbitrary scale. Taking the other indifference points to calculate the utility associated with as follows:

$\mathrm{U}(200)=0.8 * \mathrm{u}(1000)+0.2 * \mathrm{u}(-$ $1000)=0.8 * 10+0=8$

$\mathrm{U}(-300)=0.6 * \mathrm{u}(1000)+0.4 * \mathrm{u}(-$ $1000)=0.6 * 10+0=6$

$\mathrm{U}(-600)=0.4 * \mathrm{u}(1000)+0.6 * \mathrm{u}(-$ $1000)=0.4 * 10+0=4$

$\mathrm{U}(-900)=0.2 * \mathrm{u}(1000)+0.8 * \mathrm{u}(-$ $1000)=0.2 * 10+0=2$

$\mathrm{U}(-1000)=0.0 * \mathrm{u}(1000)+1.0 * \mathrm{u}(-$ $1000)=0.0 * 10+0=0$ 
Emir. J. Food Agric. 2009. 21 (2): 51-63

http://cfa.uaeu.ac.ae/ejfa.shtml

Table 2. Choice Table for Finding Indifference Points between Certain Cash and Various Reference Contracts.

\begin{tabular}{|c|c|c|c|c|c|c|}
\hline \multirow{3}{*}{$\begin{array}{c}\text { Certain Cash } \\
\text { Alternative B } \\
\text { (J. D.) }\end{array}$} & \multicolumn{6}{|c|}{ Reference contract with probability $P$} \\
\hline & \multicolumn{6}{|c|}{ (Alternative A) } \\
\hline & $\mathbf{P}=\mathbf{1 . 0}$ & $\mathrm{P}=0.8$ & $P=0.6$ & $P=0.4$ & $P=0.2$ & $P=0$ \\
\hline-1100 & A & A & A & A & A & A \\
\hline-1000 & A & $\mathrm{A}$ & $\mathrm{A}$ & A & $\mathrm{A}$ & $\mathrm{I}$ \\
\hline-900 & A & $\mathrm{A}$ & A & $\mathrm{A}$ & I & B \\
\hline-800 & A & A & A & A & B & B \\
\hline-700 & A & $\mathrm{A}$ & $\mathrm{A}$ & $\mathrm{A}$ & B & $\mathrm{B}$ \\
\hline-600 & $\mathrm{~A}$ & A & $\bar{A}$ & I & B & B \\
\hline-500 & $\mathrm{~A}$ & A & $\mathrm{A}$ & B & $\mathrm{B}$ & $\mathrm{B}$ \\
\hline-400 & A & $\mathrm{A}$ & $\mathrm{A}$ & B & B & B \\
\hline-300 & $\mathrm{~A}$ & $\mathrm{~A}$ & I & $\mathrm{B}$ & $\mathrm{B}$ & $\mathrm{B}$ \\
\hline-200 & A & $\mathrm{A}$ & B & B & B & B \\
\hline-100 & A & $\mathrm{A}$ & $\mathrm{B}$ & $\mathrm{B}$ & B & $\mathrm{B}$ \\
\hline 0 & $\mathrm{~A}$ & $\mathrm{~A}$ & B & $\mathrm{B}$ & B & B \\
\hline 100 & $\mathrm{~A}$ & $\mathrm{~A}$ & $\mathrm{~B}$ & $\mathrm{~B}$ & $\mathrm{~B}$ & $\mathrm{~B}$ \\
\hline 200 & A & I & B & $\mathrm{B}$ & $\mathrm{B}$ & $\mathrm{B}$ \\
\hline 300 & A & $\mathrm{B}$ & $\mathrm{B}$ & $\mathrm{B}$ & $\mathrm{B}$ & $\mathrm{B}$ \\
\hline 400 & A & B & $\mathrm{B}$ & B & B & B \\
\hline 500 & $\mathrm{~A}$ & $\mathrm{~B}$ & $\mathrm{~B}$ & $\mathrm{~B}$ & $\mathrm{~B}$ & $\mathrm{~B}$ \\
\hline 600 & $\mathrm{~A}$ & $\mathrm{~B}$ & B & B & B & $\mathrm{B}$ \\
\hline 700 & A & $\mathrm{B}$ & $\mathrm{B}$ & $\mathrm{B}$ & $\mathrm{B}$ & B \\
\hline 800 & $\mathrm{~A}$ & $\mathrm{~B}$ & $\mathrm{~B}$ & $\mathrm{~B}$ & $\mathrm{~B}$ & $\mathrm{~B}$ \\
\hline 900 & $\mathrm{~A}$ & B & B & B & B & B \\
\hline 1000 & I & B & B & B & B & B \\
\hline 1100 & $\mathrm{~B}$ & $\mathrm{~B}$ & $\mathrm{~B}$ & $\mathrm{~B}$ & $\mathrm{~B}$ & $\mathrm{~B}$ \\
\hline
\end{tabular}

$\mathrm{A}=$ Alternative $\mathrm{A}, \mathrm{B}=$ Alternative $\mathrm{B}, \mathrm{I}=$ Indifference points 